\title{
Modelling and Simulation for Used Genetic Algorithm Method to Speed Control of Three-phase Induction Motor
}

\author{
Joko Kusnandi", Harnoko Stephanus, Sasongko Pramono Hadi \\ Department of Electrical Engineering, Technology Information Faculty, Engineering University, Indonesia
}

Copyright $(2016$ by authors, all rights reserved. Authors agree that this article remains permanently open access under the terms of the Creative Commons Attribution License 4.0 International License

\begin{abstract}
Optimization techniques are very well-known to improve the performance of Three-phase induction motor (TIM). Inverter and SVPWM method can be used for setting voltage and frequency appropriating with loads requirements. This study deals with the tuning of PID controller parameters to be used TIM. Genetic algorithm is used to tune each parameters of PID speed controller to improve the speed response performance of the TIM. PID-GA aims to minimize the error signal speed of TIM, reduce overshoot, and tune parameters of PID controller. The error signal speed of TIM has objective function from integrated error signal (ISE). Parameters of PID controller from optimization are used to the model of the closed-loop speed control of three-phase induction motor using PID. PID-GA has the best speed response. On the model of the closed-loop speed control of three-phase induction motor using PID, various load torque can result in decreasing flux stator and rotor, increasing current stator and rotor, and decreasing speed of the induction motor.
\end{abstract}

Keywords Three-phase Induction Motor, Inverter, SVPWM, Genetic Algorithm, PID

\section{Introduction}

Electricity demand has increased everytime and the growth in the industrial sector leads to modernization. Most electricity in the industrial sector is consumed by electric motors. Over $90 \%$ industrial sector uses three-phase induction motors because the price is relatively cheap, robust contruction, and easy maintenance.

Source of electrical energy from the power network is limited to a certain voltage and frequency making it difficult to control the speed of induction motor. Inverter and space vector pulse width modulation (SVPWM) can be used for setting voltage and certain frequency corresponding load requirements. SVPWM has the advantage to reduce total harmonic distortion (THD)[8][12].
The rapid development of power electronic devices and converter technologies in the past few decades, however, has made possible efficient speed control by varying the supply frequency, giving rise to various forms of adjustable-speed induction motor drives. Researchers soon realized that the performance of induction motor drives can be enhanced by adopting artificial intelligence based methods. Artificial intelligent techniques mean use of expert system, fuzzy logic, neural networks and genetic algorithm. Artificial Intelligent Controller (AIC) could be the best controller for induction motor control. Researchers has developed hybrid controller for speed control induction motor [1][5][10][12][17][19]. A hybrid controller is that with a combination of fuzzy logic and neural network, such as uncertainty or unknown variations in plant parameters and structure can be dealt more effectively.

This paper purposes to develop PID-GA controller for controlling speed of three-phase induction motor. PID controller can solve many problem such as high overshoot, high steady state error, and oscillation speed response system. Genetic algorithm can produce the best solution global [3][7][18]. Genetic algorithm can prevent local optimum condition because it uses several point as initialize value.

Metaheuristic optimization techniques of genetic algorithm can be used to optimize error signal using intergated square error (ISE). Genetic algorithm will tune parameters PID controller such as $\mathrm{Kp}, \mathrm{Ki}$, and $\mathrm{Kd}$ so that it can work. PID-GA controller be hoped control speed of TIM.

\section{Dynamic Model of Three-phase Induction Motor}

Dynamic model of three-phase induction motor can utilise mathematical model to some stationary equation. Variable equation stator and rotor such as voltage, current, and flux linkage can be converted to dq-axis reference frame. The flux linkage can be found the equation following [2][10][14]: 


$$
\begin{gathered}
\frac{1}{\omega_{b}} \frac{d \psi_{q s}}{d t}=v_{q s}-R_{S} i_{q s}-\frac{\omega_{e}}{\omega_{b}} \psi_{d s} \\
\frac{1}{\omega_{b}} \frac{d \psi_{d s}}{d t}=v_{d s}-R_{S} i_{d s}+\frac{\omega_{e}}{\omega_{b}} \psi_{q s} \\
\frac{1}{\omega_{b}} \frac{d \psi_{q r}}{d t}=v_{q r}-R_{r} i_{q r}-\frac{\left(\omega_{e}-\omega_{r}\right)}{\omega_{b}} \psi_{d r} \\
\frac{1}{\omega_{b}} \frac{d \psi_{d s}}{d t}=v_{d r}-R_{r} i_{d r}+\frac{\left(\omega_{e}-\omega_{r}\right)}{\omega_{b}} \psi_{q r}
\end{gathered}
$$

Due to substituting the values of flux linkages as (1) to (4), generated the following current equation are obtained as :

$$
\begin{gathered}
i_{q s}=\frac{\left(\psi_{q s}-\psi_{m q}\right)}{X_{l s}} \\
i_{d s}=\frac{\left(\psi_{d s}-\psi_{m d}\right)}{X_{l s}} \\
i_{q r}=\frac{\left(\psi_{q r}-\psi_{m q}\right)}{X_{l r}} \\
i_{d r}=\frac{\left(\psi_{d r}-\psi_{m d}\right)}{X_{l r}}
\end{gathered}
$$

Where $\psi_{m q}$ and $\psi_{m d}$ are the mutual flux linkages in the (d-q) axis. The mutual flux equations are written as follows:

$$
\begin{gathered}
\psi_{m d}=X_{m l}\left(\frac{\psi_{d s}}{X_{l s}}+\frac{\psi_{d r}}{X_{l r}}\right) \\
\psi_{m q}=X_{m l}\left(\frac{\psi_{q s}}{X_{l s}}+\frac{\psi_{q r}}{X_{l r}}\right) \\
X_{m l}=\frac{\frac{1}{X_{m}}+\frac{1}{X_{l s}}+\frac{1}{X_{l r}}}{}
\end{gathered}
$$

Electromagnetic torque can be determined as follow:

$$
T_{e}=\left(\frac{3}{2}\right)\left(\frac{P}{2}\right)\left(\frac{1}{\omega_{b}}\right)\left(\psi_{d s} i_{q s}-\psi_{q s} i_{d s}\right)
$$

Relation speed induction motor and electromagnetic torque can be found following equation:

$$
T_{e}=T_{\text {Load }}+J \frac{d \omega_{m}}{d t}=T_{\text {Load }}+\frac{2 J}{P} \frac{d \omega_{r}}{d t}
$$

Rotor speed can be expressed as follow:

$$
\omega_{r}=\int \frac{P}{2 J}\left(T_{e}-T_{\text {Load }}\right) d t
$$

The design and implement depended on the above equations and of build by using MATLAB/SIMULINK and execution by using parameters in the Table 1 .

Table 1. three-phase induction motor parameters

\begin{tabular}{|c|c|c|}
\hline Parameter & Definition & Values \\
\hline $\mathrm{HP}$ & Power rated & $3 \mathrm{hp}$ \\
\hline$\omega$ & Rated speed & $1710 \mathrm{rpm}$ \\
\hline$V$ & Voltage & $220 \mathrm{~V}$ \\
\hline$f$ & Frequency & $60 \mathrm{~Hz}$ \\
\hline $\mathrm{P}$ & Number of poles & 4 \\
\hline$R_{s}$ & Stator resistance & $0.435 \mathrm{ohm}$ \\
\hline$R_{r}$ & Rotor resistance & $0.816 \mathrm{ohm}$ \\
\hline$X_{m}$ & Mutual reactance & $26.13 \mathrm{ohm}$ \\
\hline$X_{l s}$ & Stator reactance & $0.754 \mathrm{ohm}$ \\
\hline$X_{l r}$ & Rotor reactance & $0.754 \mathrm{ohm}$ \\
\hline$J$ & Inertia of motor & $0.089 \mathrm{~kg} \cdot \mathrm{m}^{2}$ \\
\hline$B_{m}$ & Friction coefficient & $0,05 \mathrm{~kg} . \mathrm{m}^{2}$ \\
\hline$\omega_{e}$ & Electrical Speed & $377 \mathrm{rad} / \mathrm{s}$ \\
\hline$\omega_{b}$ & Based speed & $377 \mathrm{rad} / \mathrm{s}$ \\
\hline$\omega_{\text {referensi }}$ & Reference speed & $1800 \mathrm{rpm}$ \\
\hline
\end{tabular}

\section{Svpwm Technique}

SVPWM technique is special switching scheme of six power IGBTs of a 3-phase inverter. It is one best way the Pulse Width Modulation (PWM) due to reduce minimum Total Harmonics Distortion (THD)[8][12]. Operation principle is rotation of this space vector can be executed by variable frequency device to generate three phase sine waves to go TIM. The three-phase voltage source can be changed to a space vector using following equation [12]:

$$
V=v_{a} e^{j 0}+v_{b} e^{j 2 \pi / 3}+v_{c} e^{4 \pi / 3}
$$

Control signal of SVPWM techniuqe based on using following equation[12]:

$$
\begin{aligned}
& \frac{V_{\text {control-a }}}{V_{\text {tri }}}=\frac{\left(v_{a}-\left(\frac{\max \left(v_{a}\right)+\min \left(v_{a}\right)}{2}\right)\right)}{V_{d}} \\
& \frac{V_{\text {control-b }}}{V_{\text {tri }}}=\frac{\left(v_{b}-\left(\frac{\max \left(v_{b}\right)+\min \left(v_{b}\right)}{2}\right)\right)}{V_{d}} \\
& \frac{V_{\text {control-c }}}{V_{\text {tri }}}=\frac{\left(v_{c}-\left(\frac{\max \left(v_{c}\right)+\min \left(v_{c}\right)}{2}\right)\right)}{V_{d}}
\end{aligned}
$$

Trigger signal is applied a triangle wave using switching frequency $f_{s}$. SVPWM is taken from comparison control signal SVPWM and trigger signal. 


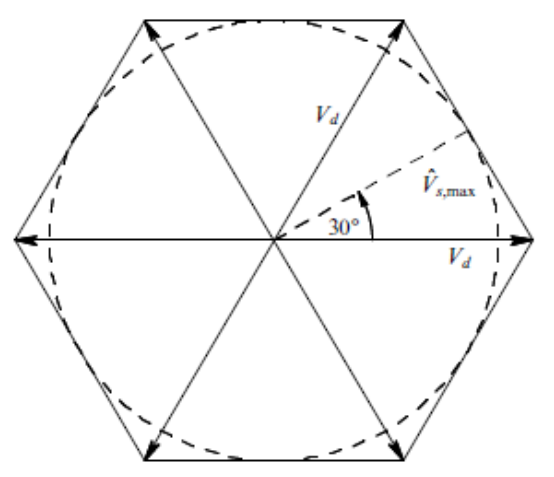

Figure 1. Space vector limited amplitude

\section{Genetic Algorithm}

Genetic algorithm [20] is stochastic techniques to optimize based on the natural selection mechanism and genetic, which work with a population of solution. A fitness value derived from the problem's objective function is assigned to each member of the population. Individuals that represent better solutions are awarded higher fitness value, thus enabling them to survive more generation. Commencing with an initial random population, successive generations of population are created by the operators reproduction, crossover and mutation to yield better solutions, which approach the optimal solution to the problem

The Genetic Algorithm (GA) offers an effective way for automatically searching or tuning of PID parameter [21] according to the dynamic behavior and signals of the measured system. It performs especially well when solving complex problems because it does not impose many limitations of traditional teheniques. The better performance is obtained because of global and robust nature of GA, its ability of locating high performance areas in complex domains without experiencing the difficulties associated with high dimensionality or false optimation, and its computational efficiency. The technique has the capability to solve nonlinear and complex optimization problems. PID controller has good performance and have been applied in practice.

\section{Design Tuning Pid-Ga}

PID control system consists of three ways such as $\mathrm{P}$ (proportional), D (Derivative), and I (Integral), which each parameter has advantages and disadvantages. In the implementation of each way can work alone or combined. In the design of PID control system needs to be done is to set the parameters $\mathrm{P}, \mathrm{I}$, and $\mathrm{D}$ in order to the response of the output signal of system against certain entries as desired. PID control will correct error between the output with the input or settting point by caculating and give correction output [14]. In general, the PID controller has form of equation (17)[13].

$$
u(t)=K_{p} e(t)+K_{i} \int_{0}^{t} e(t) d t+K_{d} \frac{d e(t)}{d t}
$$

If equation (17) is converted to be PID controller transfer function, so that it will become equation (18)

$$
G(s)=K_{p}+\frac{K_{i}}{s}+s K_{d}
$$

Where $\mathrm{K}_{\mathrm{p}}$ is the proportional gain, $\mathrm{K}_{\mathrm{i}}$ is the integral gain, and $\mathrm{K}_{\mathrm{d}}$ is the derivative gain.

Performance criteria is intergated of square error (ISE) that can be evaluated analytical in the frequency domain. ISE performance criterion formula is as follow:

$$
I S E=\int_{0}^{\infty} e^{2}(t) d t
$$

where $e(t)=\omega_{\text {reference }}-\omega_{\text {rotor }}$. Figure. 2 show that flowchart of PID-GA speed controller.

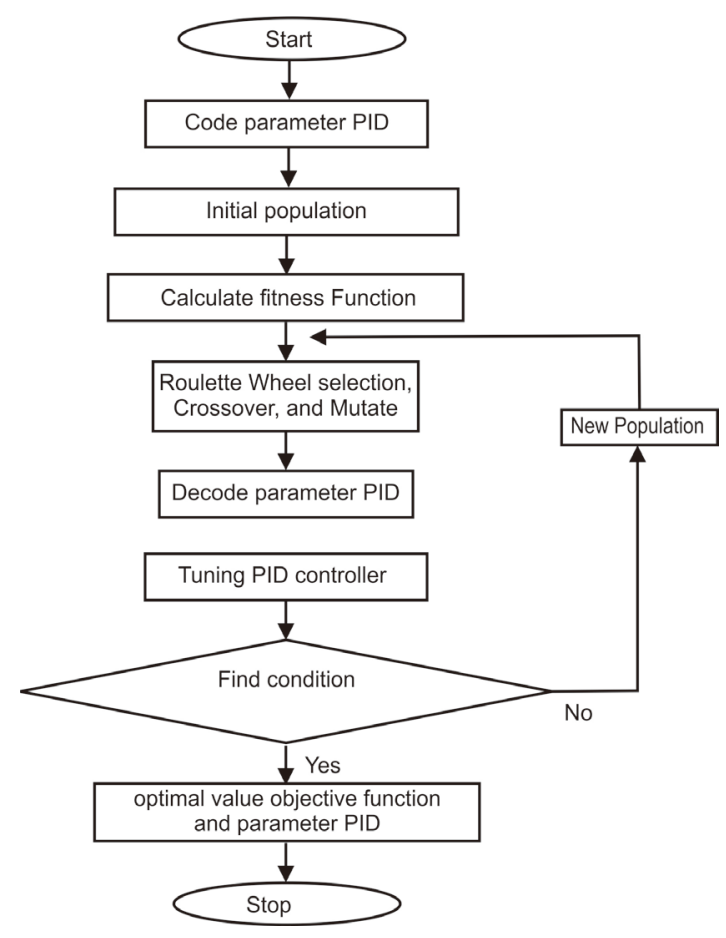

Figure 2. Flowchart PID-GA

Performance is measured by combination overshoot and ISE. It is entried to equation of time domain response. The objective function, $f$ is applied to evaluate the performance given by,

$$
f=\alpha \times O S+\beta \times I S E
$$

where $\alpha$ and $\beta$ as weight constant each element of objective function, OS shown overshoot of speed response and ISE refers to integrated square.

Plant in model PID-AG apply a simple equation. It consists of an actuator and transfer function. Relation mechanic speed and torque of induction motor without load can be used a transfer function passing Laplace transform. It is noticed by equation (20). Mechanism of PID-GA is shown by Figure.3. 


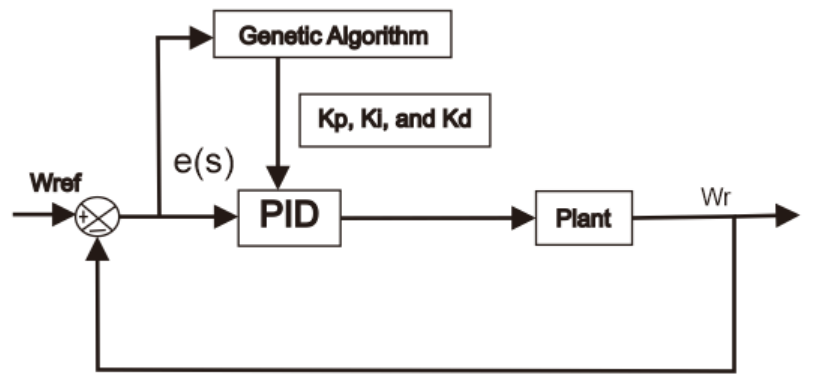

Figure 3. Block mechanism of PID-GA

$$
G(s)=\frac{\omega_{m}(s)}{T_{e}(s)}=\frac{1}{J_{S}+B_{m}}
$$

Parameters of genetic algorithm is shown on the Table.2, whereas contraint parameter PID is noticed by Table 3.

Table 2. Parameter Genetic Algorithm

\begin{tabular}{|c|c|}
\hline Parameters & Values \\
\hline Population size & 30 \\
\hline Maximum generation & 50 \\
\hline Selection method & Roulette wheel \\
\hline Crossover percentage & 0,8 \\
\hline Extra range factor for crossover & 0,4 \\
\hline Mutation percentage & 0,3 \\
\hline Mutation rate & 0,1 \\
\hline
\end{tabular}

Table 3. Contraint of Parameter Pid

\begin{tabular}{|c|c|c|c|}
\hline Parameter PID & Kp & Ki & Kd \\
\hline Minimum & 0 & 0 & 0 \\
\hline Maximum & 5 & 5 & 5 \\
\hline
\end{tabular}

\section{Block MATLAB/SIMULINK}

This section, mechanism of PID-GA is separated by closed-loop speed control of three-phase induction motor using PID. Genetic algorithm is used to tuning parameter $\mathrm{K}_{\mathrm{p}}$, $\mathrm{K}_{\mathrm{i}}$, dan $\mathrm{K}_{\mathrm{d}}$. Optimation error signal is shown by equation (18). Whereas objective function refer to equation (19). Plant of induction motor only apply an simple equation which noticed by equation (20). Block mechanism PID-GA in MATLAB/SIMULINK is shown by Figure.4

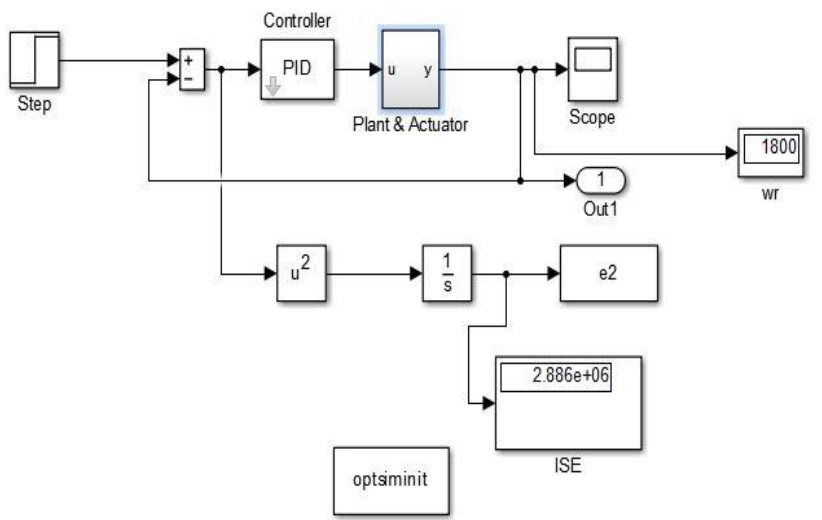

Figure 4. Block mechanism design tuning PID-GA in MATLAB/SIMULINK
Block closed-loop speed control of three-phase induction motor using PID is shown by Figure.5. It consists of block reference speed, block PID, block sinusoidal wave voltages controller, block SVPWM, block inverter, block filter, and block of dynamic induction motor. Block of dynamic induction motor uses DQ model. It is taken from equation (1)-(13). Block SVPWM is made from comparison signal voltages abc controller with signal trigger wave uses switching frequency fs.

\section{Simulation Result}

In the first case, simulation PID-GA is worked. Tuning of PID controller parameters is gained in simulation and shown on Table 4.

Table 4. Parameters Pid-Ga

\begin{tabular}{|c|c|c|c|}
\hline Methods & Kp & Ki & Kd \\
\hline GA & 3,4224 & 0,03291 & 4,4379 \\
\hline
\end{tabular}

Whereas performance index consists of overshoot and ISE. It is looked at in Table. 5

Table 5. Performance index of objective function pid-ga

\begin{tabular}{|c|c|c|}
\hline Method & OS & ISE \\
\hline GA & $0,5 \%$ & $2.919 \mathrm{e}+06$ \\
\hline
\end{tabular}

Graph optimal value of objective function genetic algorithm is noticed in Figure. 6 and Graph response speed of induction motor using PID-GA is shown by Figure.7.

In other hand, simulation of the closed-loop speed control of three-phase induction motor using PID has resulted in form voltages abc controller, SVM, SVPWM, voltages of inverter, voltages inverter has been filtered, voltages dq, stator flux, rotor flux, mutual flux, stator current, rotor current, torque, and speed response of three-phase induction motor.

System response is applied variation load torque $20 \mathrm{Nm}$ at $1 \mathrm{sec}, 40 \mathrm{Nm}$ at $1.25 \mathrm{sec}$, and $60 \mathrm{Nm}$ at $1.5 \mathrm{sec}$. In the starting the operating full speed $(1800 \mathrm{rpm})$ but no load until $1 \mathrm{sec}$. change the load torque will effect to decrease flux (Figure 14-16), and to derive speed response (Figure 19).

Table 6 summarizes the effect load torque to flux induction motor and Table 7 shows result in influence load torque to speed response.

Figure 8 explains signals of voltages control phase a, phase b, and phase c. Magnitude of Voltages controller is used 1 volt.

Figure 9 demonstrates output of voltages SVM. It is seem that has magnitude 0.98 because SVM uses value of modulation 0.98 .

Figure 10 shows that It is output of SVPWM. It is used as power switching to impulse gate from inverter.

Figure 11 describes that It uses 240 volt for Inverter.

Figure 12 draws that It is output of signal exited filter. This voltages have 236 volt at simultion.

Figure 13 explains that It is output of voltages dq of three phase induction motor. It is seem that has about 354 volt. 


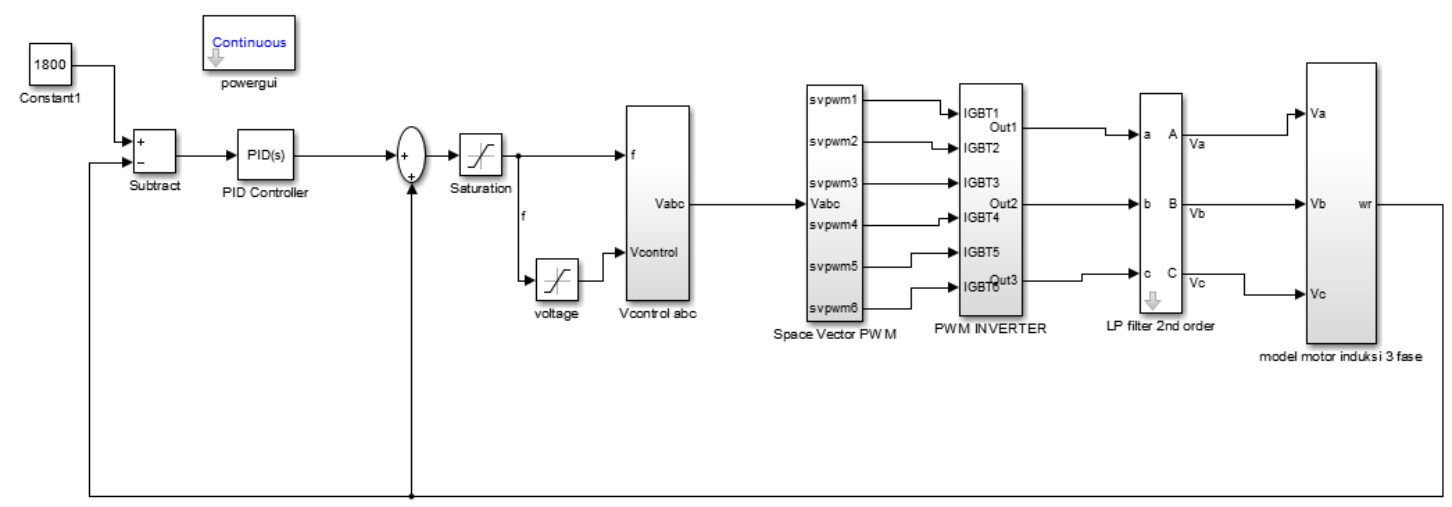

Figure 5. Closed-loop speed control of three-phase induction motor using PID.

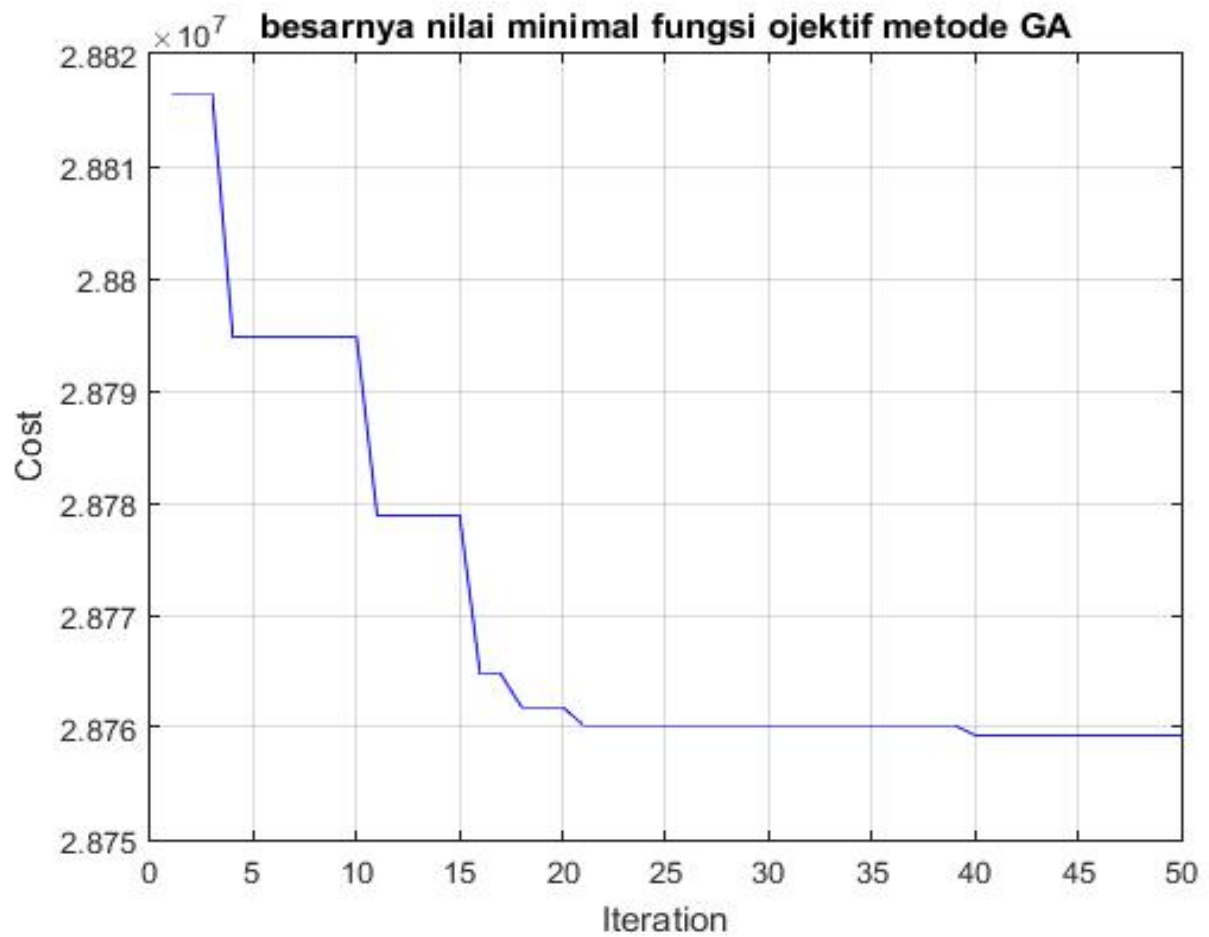

Figure 6. Optimal value of objective function PID-GA

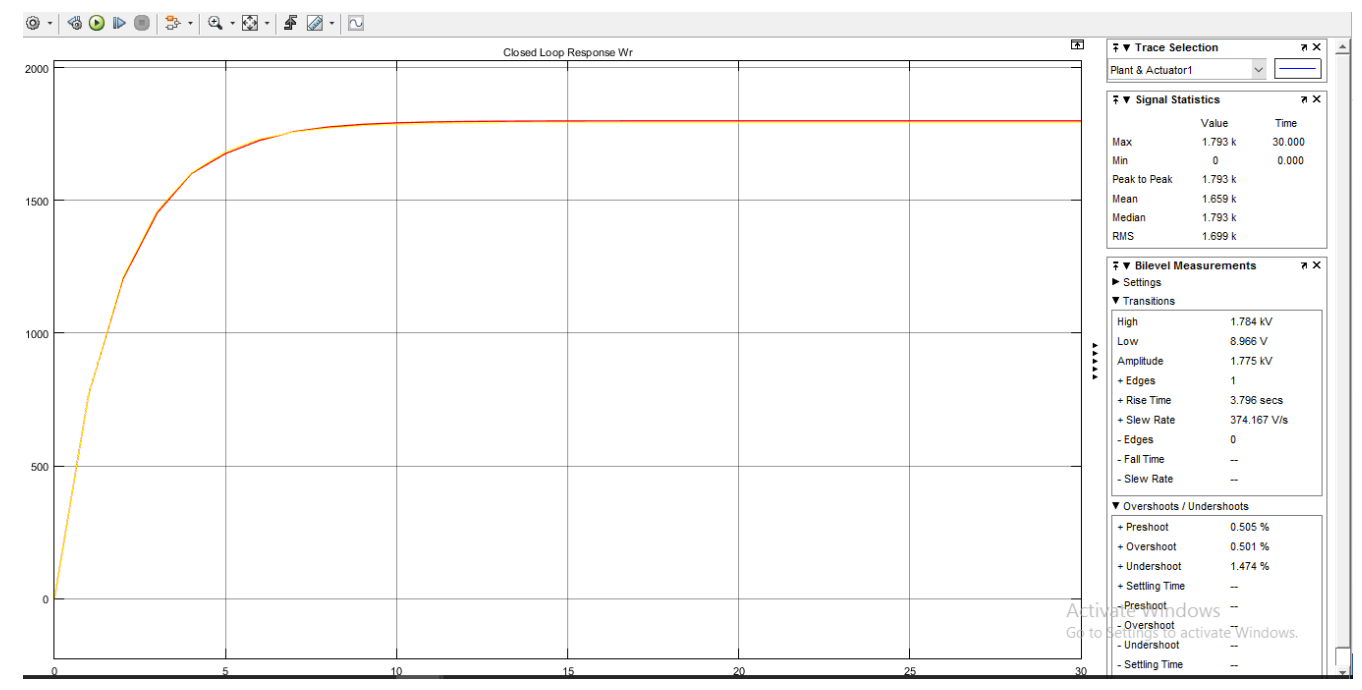

Figure 7. Response speed of induction motor using PID-GA 


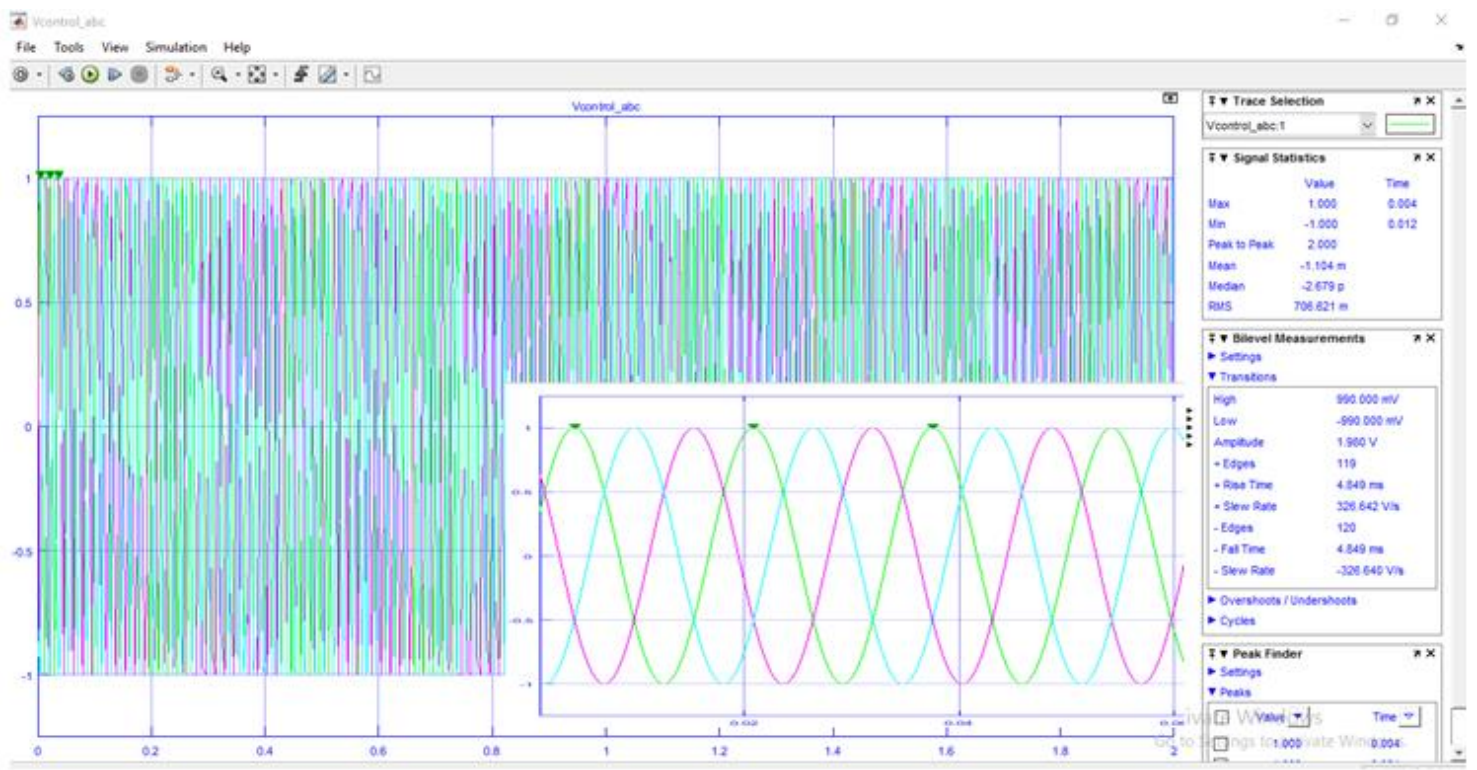

Figure 8. Voltages abc controller

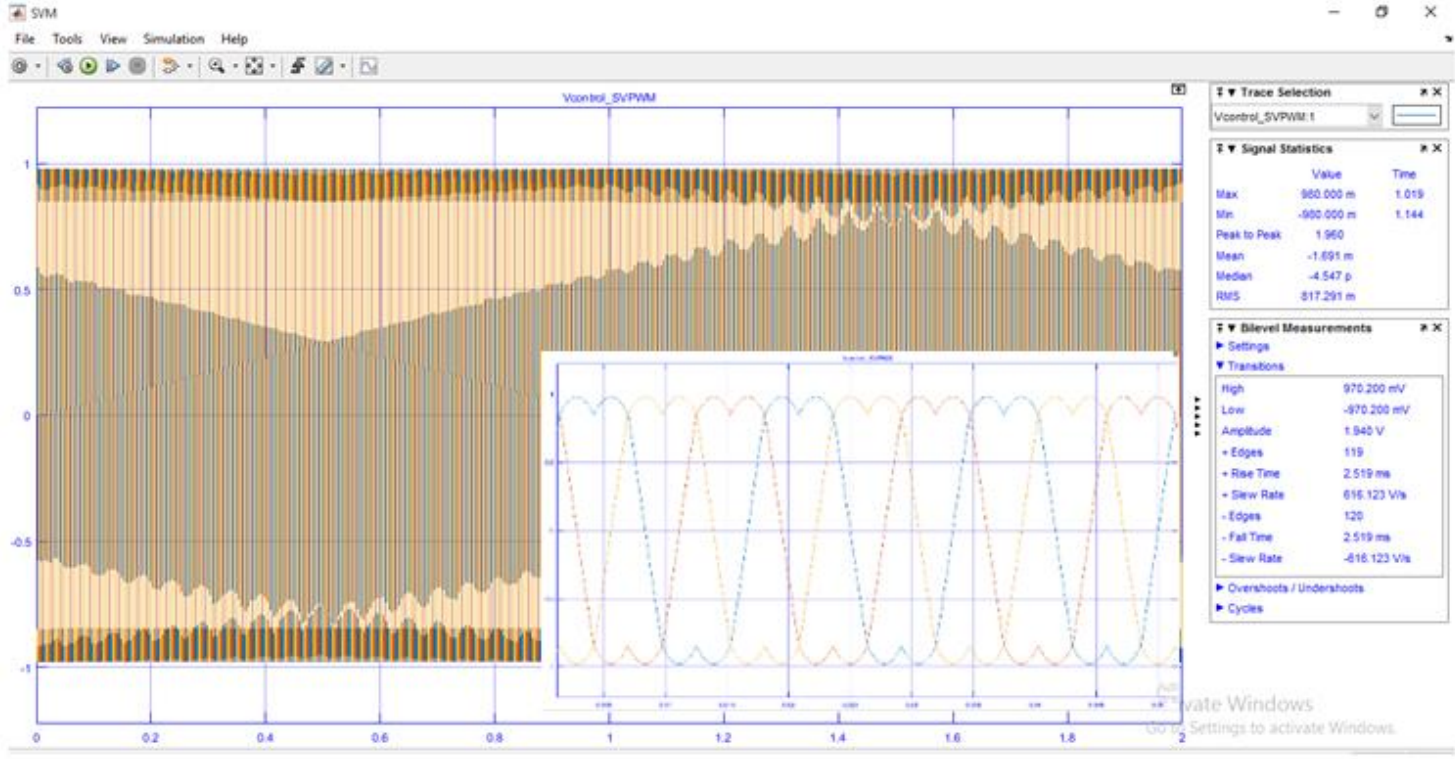

Figure 9. Voltage controller SVM 
T) s.ovin

Fien Toets Vien Simderion Hele

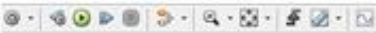

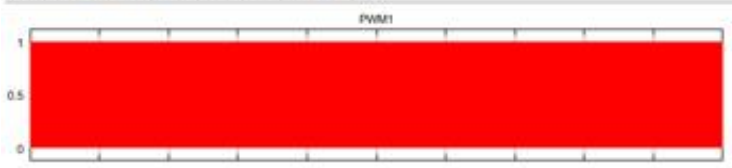

mans

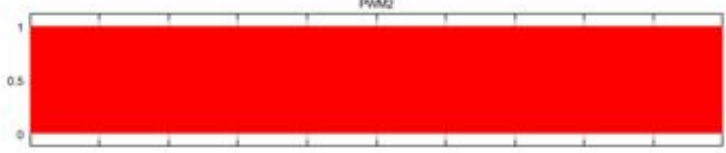

man

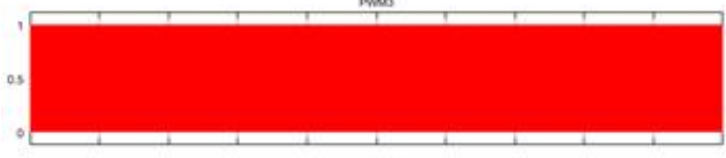

manes

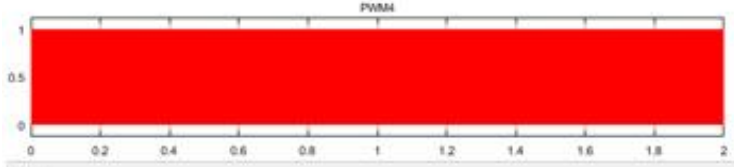

Mesody

Figure 10. SVPWM

4) v-la

File Toobs View Simulation Help

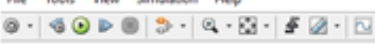

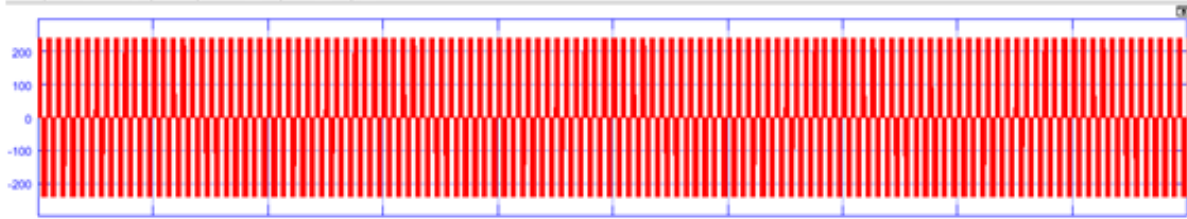

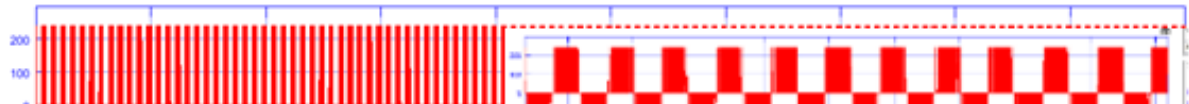

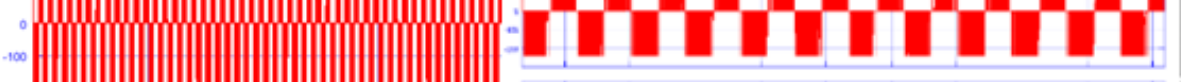

-

-

momm

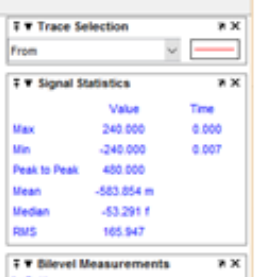

Tromener

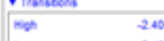

Low $2400 \mathrm{~V}$

-topest

- Rever Tise 0.000 neca

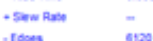

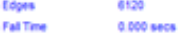

- Serw Resor -

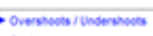

- Cycea

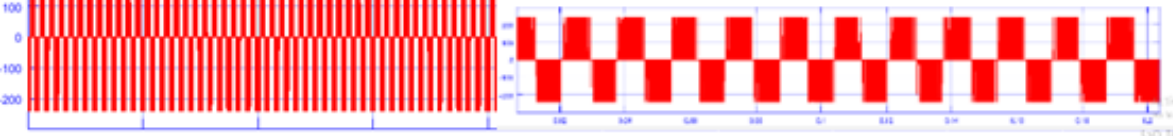

te Windows

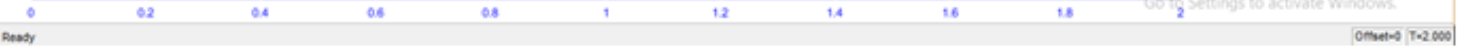

Figure 11. Voltages inverter 
El vabc have passed athe

Fie Tools View Simulation Hel

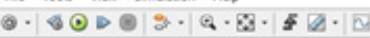

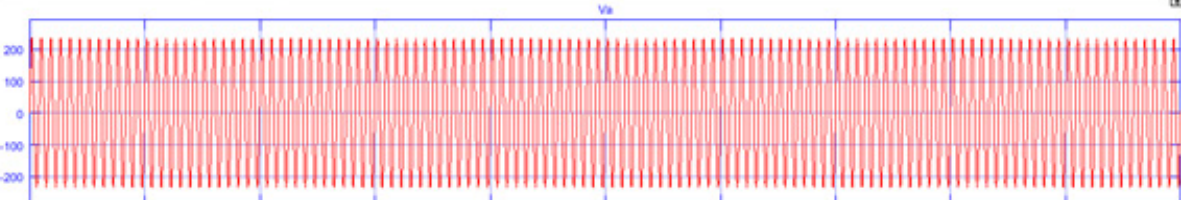

(1)

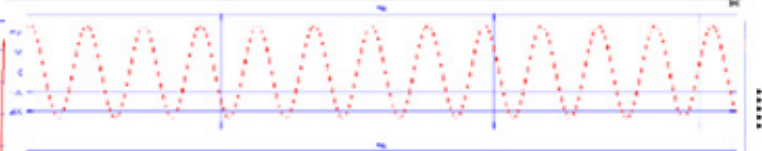

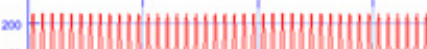

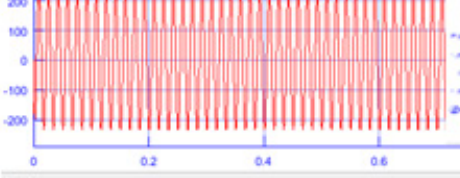
$+7$

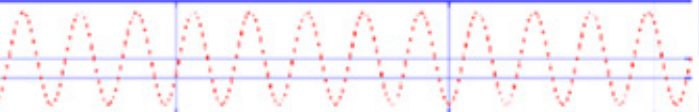

$\cdots+$

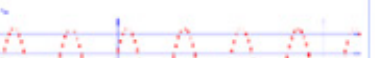

$\frac{i n}{i n}$
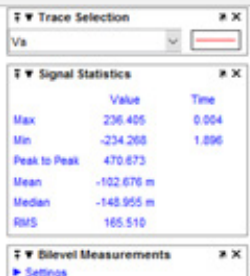

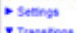

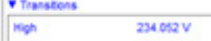

lom

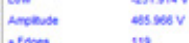

topen in

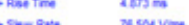

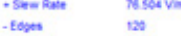

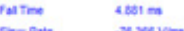

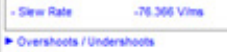

- orces

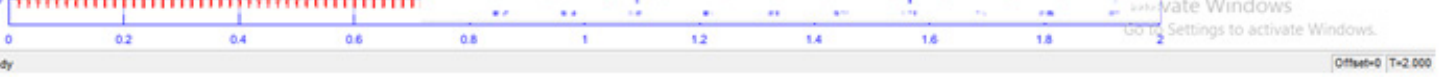

Figure 12. Voltages inverter hase been filtered

[. vaq

File Took View Simulation Help

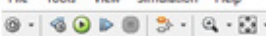
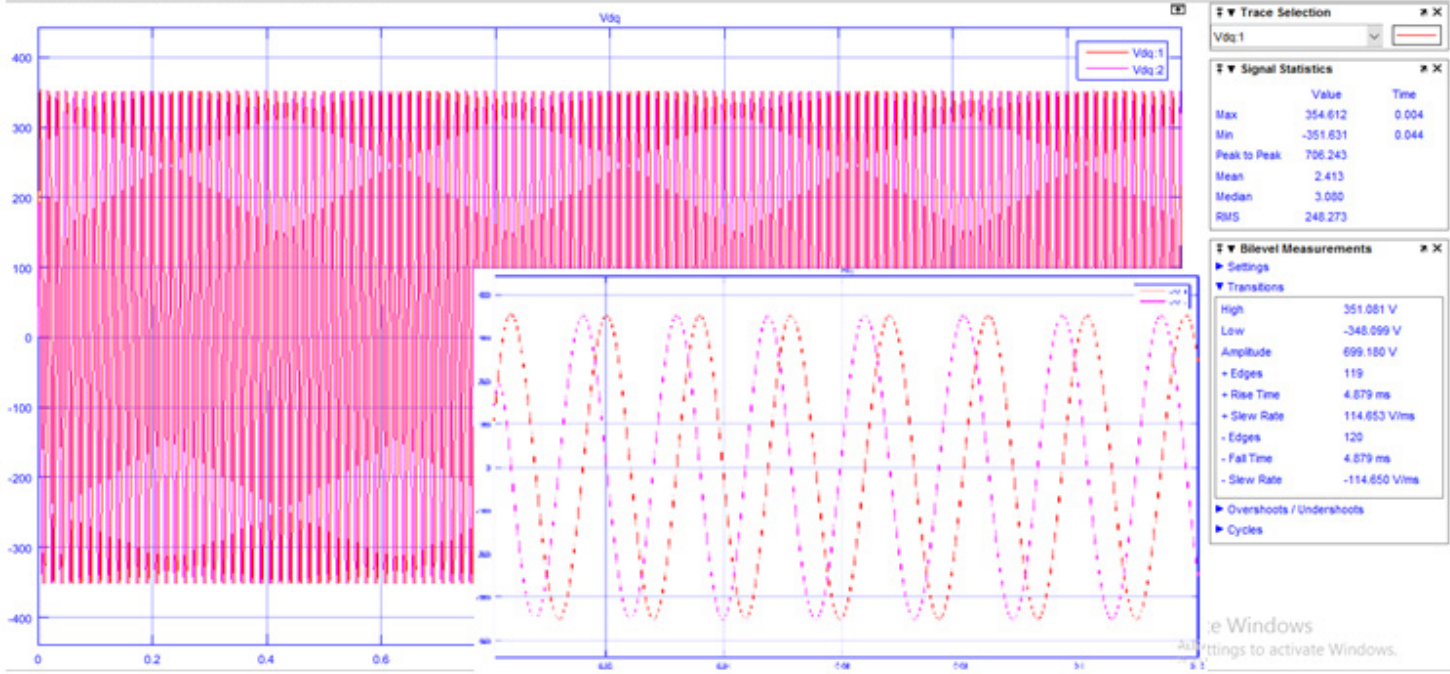

Figure 13. Voltages Vdq 
As Fluks Stator

File Tools View Simulation Help

File Tools View Simulation Help
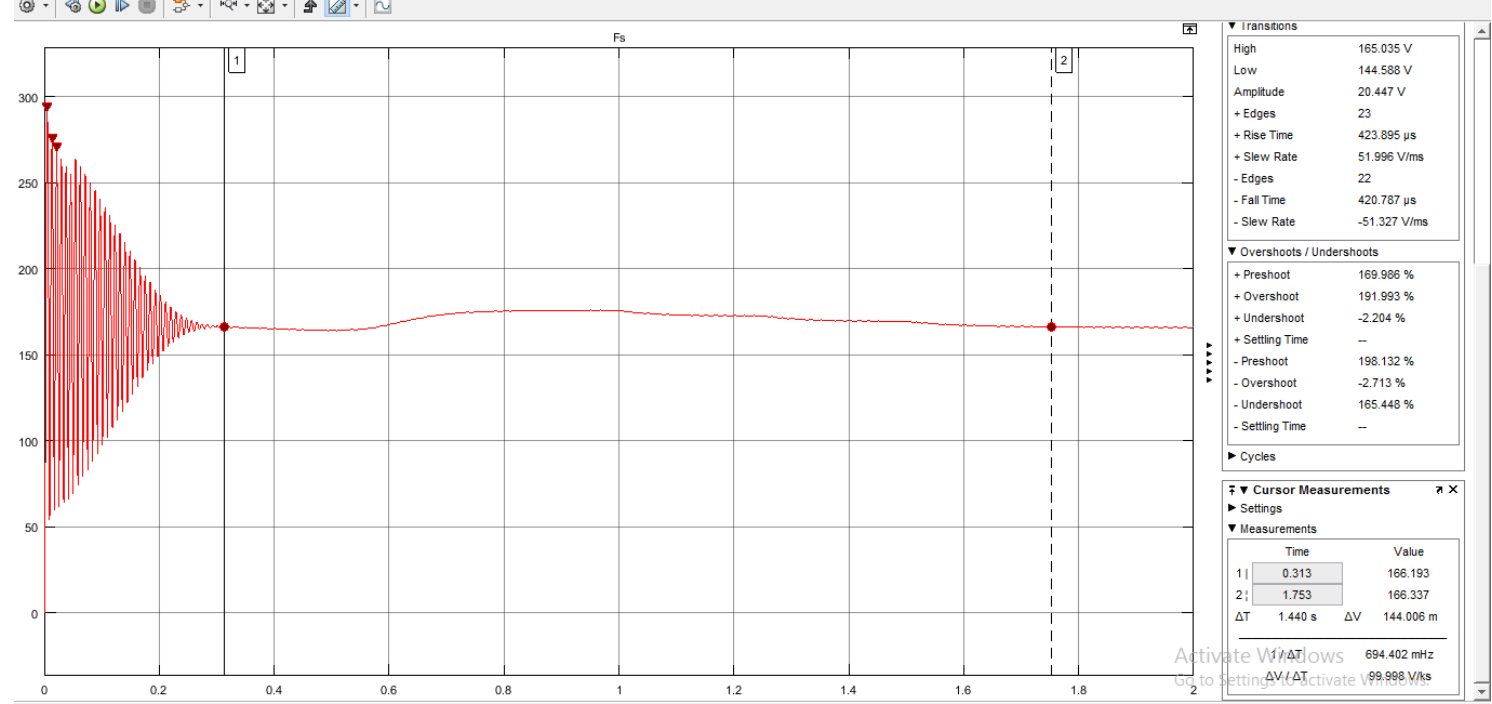

Figure 14. Stator flux

A4 Fluks rotor

File Tools View Simulation Help

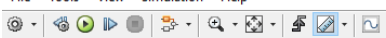
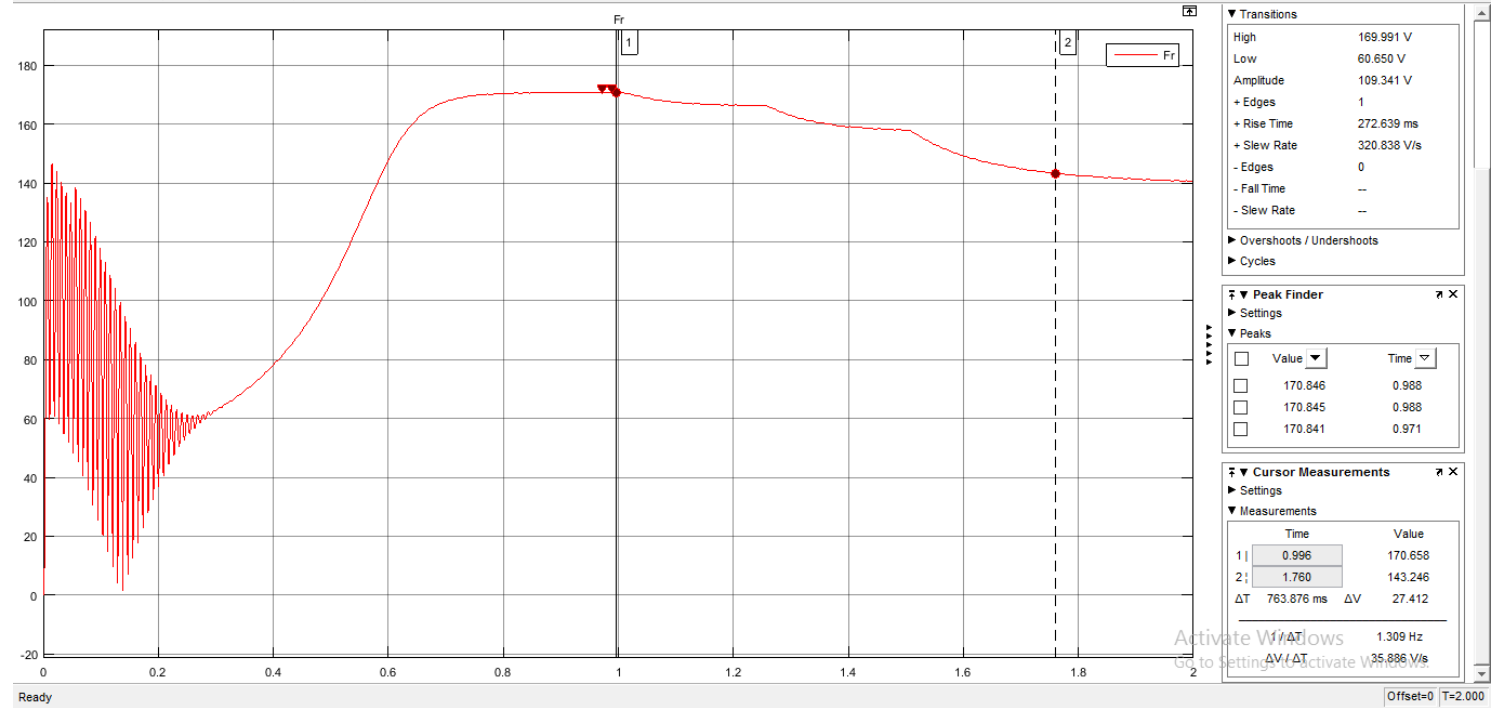

Figure 15. Rotor Flux 


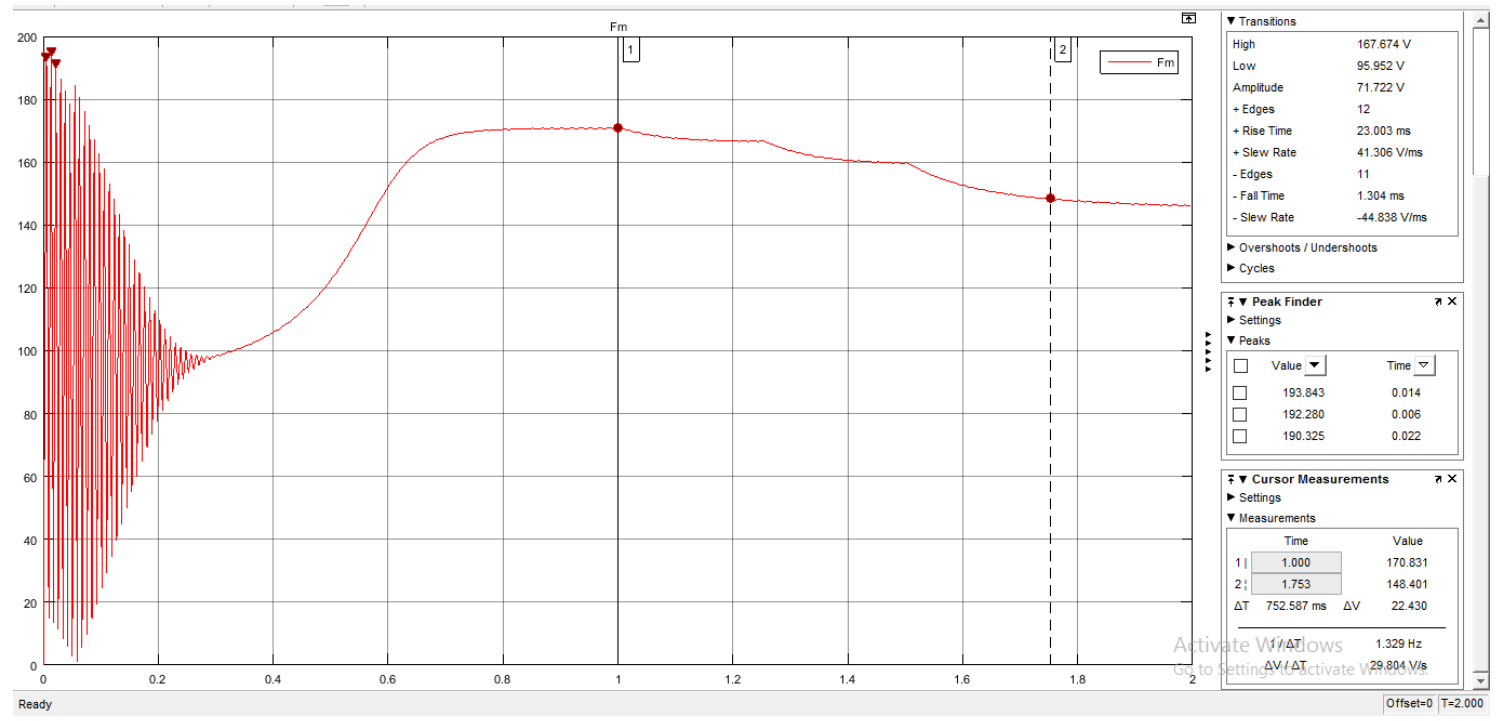

Figure 16. Mutual Flux

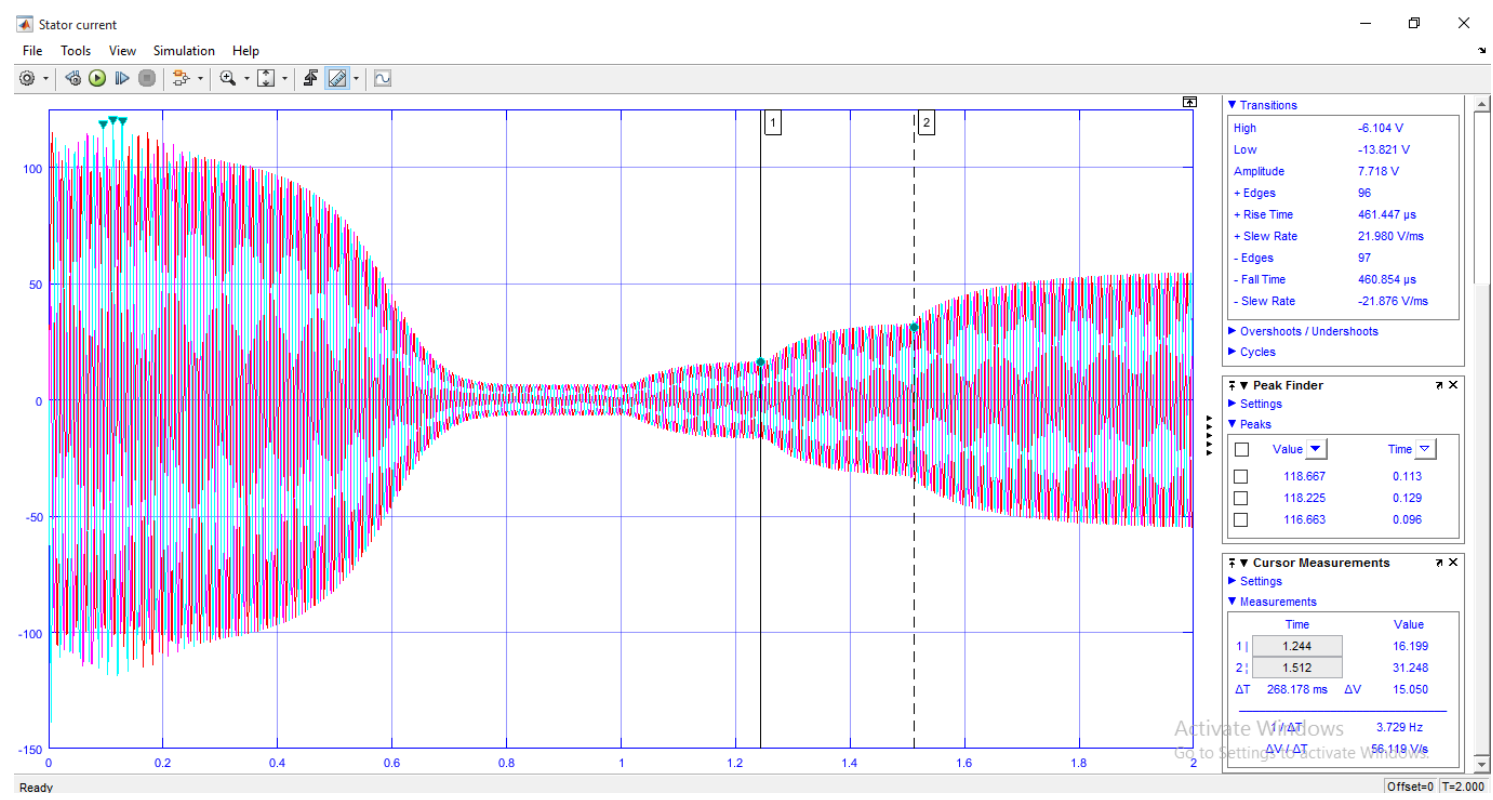

Figure 17. Stator current 
A. rotor current

File Tools View Simulation Help

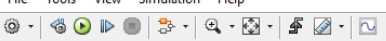
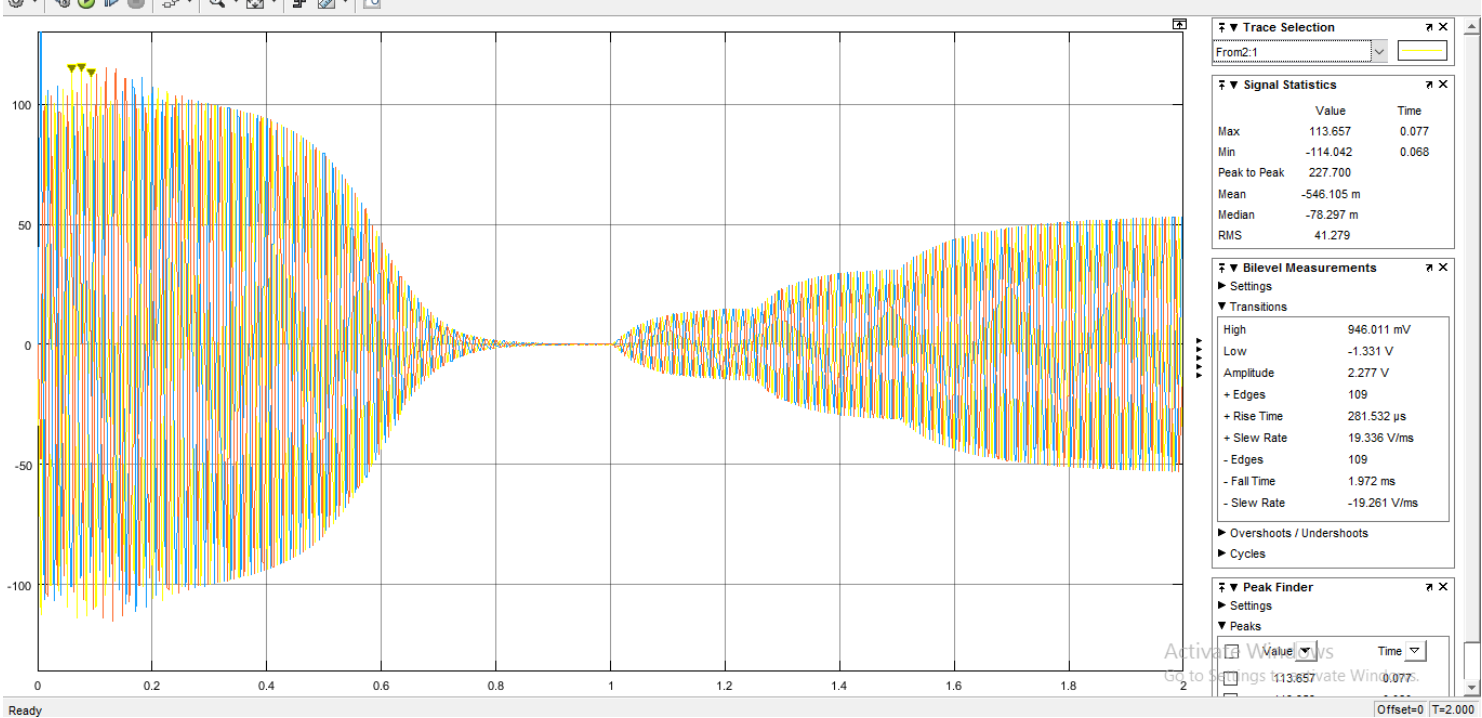

Figure 18. Rotor current

A. Torsi dan kecepatan rotor

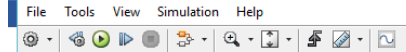
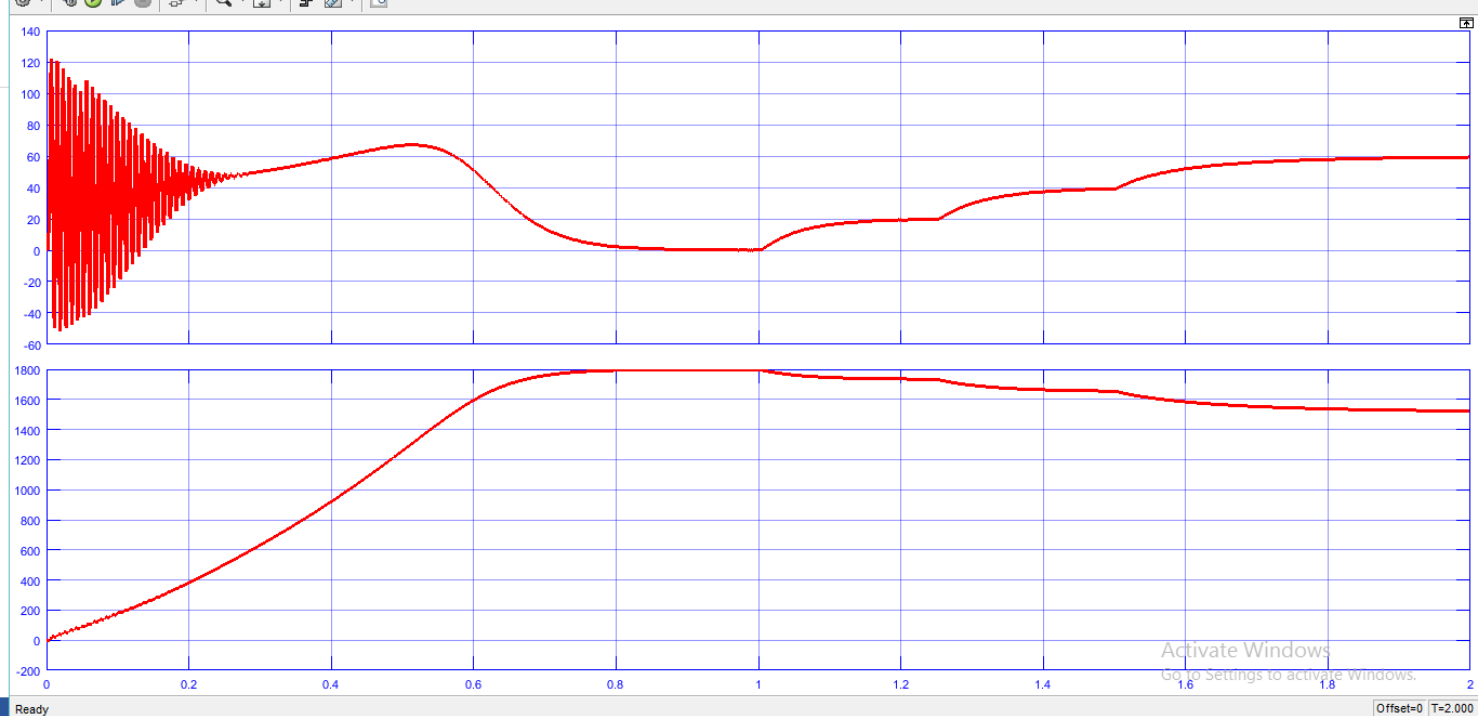

Ready

Figure 19. Torque and speed induction mtoor

Table 6. Effect load torque to flux induction motor

\begin{tabular}{|c|c|c|c|c|}
\hline Time (second) & Load Torque $T_{L}(\mathbf{N m})$ & Rotor Flux Fr (Wb) & Stator Flux Fs (Wb) & Mutual Flux Fm (Wb) \\
\hline $0-0.7$ & 0 & 167 & 173 & 168 \\
\hline $0.7-0.9$ & 0 & 170 & 175 & 170 \\
\hline $1-1.25$ & 20 & 166 & 172 & 166 \\
\hline $1.25-1.5$ & 40 & 157 & 169 & 160 \\
\hline $1.5-1.75$ & 60 & 143 & 166 & 148 \\
\hline $1.75-2$ & 60 & 140 & 165 & 146 \\
\hline
\end{tabular}


Table 7. Effect load torque to rotor speed induction motor

\begin{tabular}{|c|c|c|}
\hline Time (second) & Load Torque (Nm) & Speed (rpm) \\
\hline $0-0.65$ & 0 & $0-1710$ \\
\hline $0.65-0.93$ & 0 & $1710-1800$ \\
\hline $1-1.25$ & 20 & $1800-1734$ \\
\hline $1.25-1.5$ & 40 & $1734-1655$ \\
\hline $1.5-1.75$ & 60 & $1655-1543$ \\
\hline $1.75-2$ & 60 & $1543-1523$ \\
\hline
\end{tabular}

\section{Conclusions}

This paper presents speed control of three-phase induction motor using PID and a simple model for mechanism PID-GA. Both of them are designed is separated. At the simulation of mechanism PID-GA has been done, it had a good response system. It has found very low overshoot $0.5 \%$ and ISE $2.919 \times 10^{6}$, so the simulating shown effective performance. It also can find the tuning of the PID controller parameters for speed control of three-phase induction motor.

At the simulation experiment of closed-loop speed control of three-phase induction motor had been runned. The Rated speed $1710 \mathrm{rpm}$ can be found at the time $0.65 \mathrm{~s}$. The average starting stator current is gained $111.58 \mathrm{~A}$. The maximum starting torque is acquired $121,77 \mathrm{Nm}$. Breakdown torque or peak torque can be reach $68 \mathrm{Nm}$ at the time $0.59 \mathrm{~s}$. When this simulation is added various load torque, it will gain and affect a decreasing stator flux and rotor flux, lifting stator current and rotor current, and speed of TIM will be decreased.

\section{REFERENCES}

[1] A. A. Ansari and D.M. Deshpande, "Mathematical Model of Asynchronous Machine in MATLAB Simulink," International Journal of Engineering Science and Technology, Vol. 2(5), 2010, pp1260-1267.

[2] Afianto, Rahmawan, "Simulasi pemodelan motor induksi tiga fase dengan sumbu D-Q dengan pemrograman MATLAB", Skripsi Teknik Elektro, Universitas Gadjah Mada, 2008.

[3] Agustika, Richardus Dhimas Krisnawan, "Perancangan kendali kecepatan mesin arus searah dengan menggunakan PID-Algoritma Genetika", Tesis Teknik Elektro, Universitas Gadjah Mada, 2015.

[4] Chee-Mun Ong, Dynamic Simulation of Electric Machinery using Matlab/Simulink, New Jersey: Prentice Hall, 1997.

[5] Dal Y. Ohm, Dynamic Model of induction motor for vector control, Drivetech, Inc., Blacksburg, Virginia.

[6] Fitzgerald, A.E., Uman,S. D., Kindsley, C. Jr., Electric Machinery sixth edition, New york: McGraw Hill. 2002.
[7] Goldberg, D.E. Genetic Algorithms in Search, Optimization and Machine Learning. Addison- Wesley. 1989.

[8] Ismail , Noer Aziz, "Kendali V/F motor induksi dengan metode space vector modulation untuk penyaklaran dan estimasi kecepatan berbasis back electromotive force menggunakan mikrokontroller DSPIC" Skripsi Teknik Elektro, Universitas Gadjah Mada, 2013.

[9] K. K. Chouhan and G. B. Buch, "Improved direct torque control of induction motor," 2015 International Conference on Electrical, Electronics, Signals, Communication and Optimization (EESCO), Visakhapatnam, 2015, pp. 1-5.

[10] K. L. Shi, T. F. Chan, Y. K. Wong and S. L. HO, "Modelling and simulation of the three phase induction motor Using SIMULINK,” Int.J. Elect. Enging. Educ., Vol. 36, 1999, pp. $163-172$.

[11] Maswood, A.I., and Wei, S., "Genetic algorithm based solution in PWM converter switching", IEE Proc. Elect. Power Appl., Vol. 152, No.3, pp. 473-478, May. 2005.

[12] Ned Mohan, Advanced Electric Drives: Analysis, Control Modeling using Simulink, USA: Wiley. 2001.

[13] Ogata, Katsuhiko, Modern Control Engineering Fifth Edition. Prentice Hall International, Inc. 2010

[14] P. C. Crause, O. Wasynczuk, S. D. Sudhoff, Analysis of Electric Machinery and Drive Systems second edition. IEEE Wiley Press. 2001

[15] P. S. Brainord, K. S. Sri and L. Dinesh, "Speed control of three-phase induction motor drives using automatically sensing controller based on fuzzy logic," 2015 International Conference on Electrical, Electronics, Signals, Communication and Optimization (EESCO), Visakhapatnam, 2015, pp. 1-6.

[16] Purwanto,Era dkk. "Pengembangan Metode Self Tuning Parameter PID Controller Dengan Menggunakan Genetic Algorithm Pada Pengaturan Motor Induksi Sebagai Penggerak Mobil Listrik", Electronic Engineering Polythecnic Institute of Surabaya (EEPIS),2010.

[17] S. J. Chapman, Electric machinery fundamentals, Singapore: McGraw-Hill. 1991.

[18] Shopova, E. G. \& Vaklieva-Bancheva, N. G. "Basic-A Genetic Algorithm for Engineering Problem Solution", Science Direct Computer and Chemical Engineering, Vol.30,pp. 1293-1309, June. 2006.

[19] Tze Fun Chan and Keli Shi, Applied intelligent control of 
induction motor drives First edition, IEEE Willey Press. 2011.

[20] M.K Hassan, N.A.M Azubir, Nizam.H.M.I, S.F Toha, and B.S.K.K Ibrahim, "Optimal Design of Electric Power Assisted Steering System (EPAS) Using GA-PID Method”, International Symposium on Robotic and Intelligent Sensors
2012, Vol. 41,pp.614-621, 2012.

[21] Avneesh Mittal, Avinashi Kapoor, T.K. Saxena," Genetic Algorithm Based Tuning of Fixed Bias PID Controller for Nonlinear Constant Temperature Water Bath under Load Disturbances", Journal Automation \& System Engineering , Vol.6-3.pp. 96-109, 2012. 